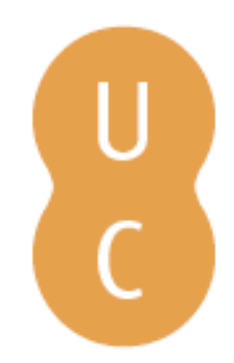

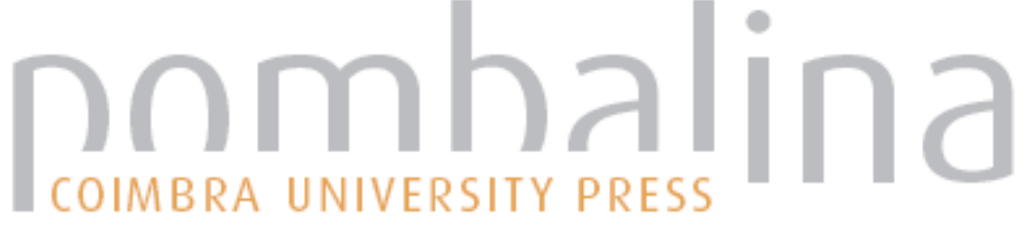

Novas tendências narrativas nas Argonáuticas de Apolónio de Rodes

Autor(es): $\quad$ Fialho, Maria do Céu

Publicado por: Centro de Estudos Clássicos e Humanísticos

URL

persistente: URI:http://hdl.handle.net/10316.2/39245

DOI: $\quad$ DOI:http://dx.doi.org/10.14195/978-989-26-1229-4_3

Accessed : $\quad$ 26-Apr-2023 16:14:56

A navegação consulta e descarregamento dos títulos inseridos nas Bibliotecas Digitais UC Digitalis, UC Pombalina e UC Impactum, pressupõem a aceitação plena e sem reservas dos Termos e Condições de Uso destas Bibliotecas Digitais, disponíveis em https://digitalis.uc.pt/pt-pt/termos.

Conforme exposto nos referidos Termos e Condições de Uso, o descarregamento de títulos de acesso restrito requer uma licença válida de autorização devendo o utilizador aceder ao(s) documento(s) a partir de um endereço de IP da instituição detentora da supramencionada licença.

Ao utilizador é apenas permitido o descarregamento para uso pessoal, pelo que o emprego do(s) título(s) descarregado(s) para outro fim, designadamente comercial, carece de autorização do respetivo autor ou editor da obra.

Na medida em que todas as obras da UC Digitalis se encontram protegidas pelo Código do Direito de Autor e Direitos Conexos e demais legislação aplicável, toda a cópia, parcial ou total, deste documento, nos casos em que é legalmente admitida, deverá conter ou fazer-se acompanhar por este aviso. 
FRANCISCO DE OLIVEIRA

PAOLO FEDELI

DELFIM LEÃO

Coordenadores

\section{- ROMANCE ANTIGO ORIGENS DE UM GÉNERO LITERÁRIO}

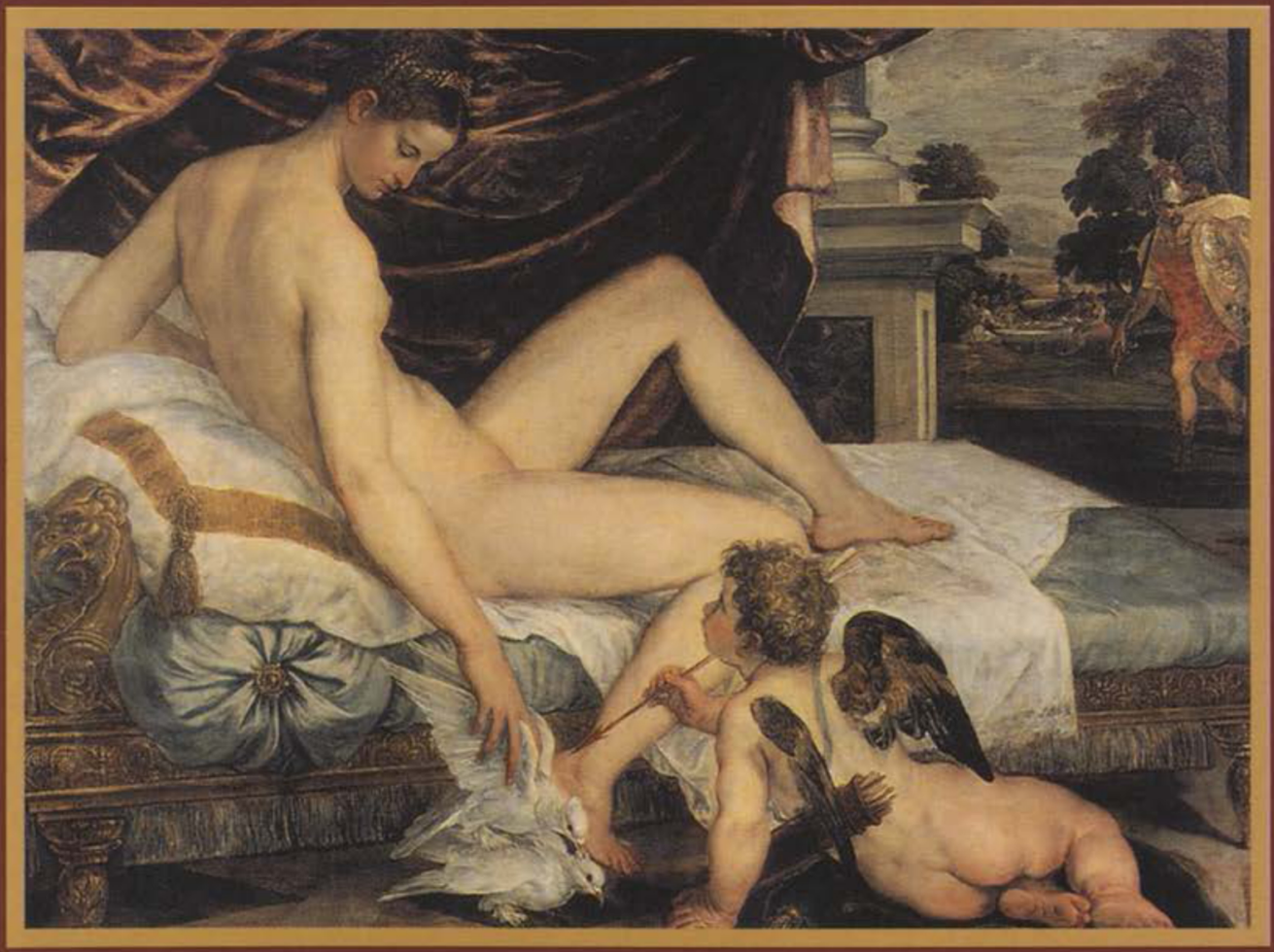

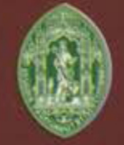

Universidade de Coimbra

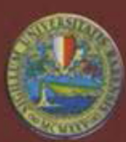

Università degli Studi di Bari

COIMBRA

2005 


\title{
NOVAS TENDÊNCIAS NARRATIVAS NAS ARGONÁUTICAS DE APOLÓNIO DE RODES
}

\author{
MARIA DO CÉU FiALHO \\ Universidade de Coimbra
}

\begin{abstract}
The sea-voyage of the Argonauts belongs to an old pattern of Hellenic narratives, even earlier than the Homeric Poems. Apollonius, in the Argonautics, rewrites the myth as an epos. His epos however, in spite of being heavily inspired on the Odyssey, shows a distancing from the genologic epic pattern in a number of ways: its structure, its portrayal of the characters, its narrative strategies. This points towards the novel. Apollonius already belongs to a period of book culture and of reading. As a matter of fact, the action begins $a b$ ovo and it is characterised by the dissymetry of the four books. The theme of the voyage looses its preponderance in relation to love and magic. Jason reveals elements of an anti-hero when confronted with Medea, who is inluenced by the tragic patterns. The narrative is sometimes characterised by a heavy lyrical presence with an increasing intervention of a narrator who is emotionally envolved with the action and aware of his task.
\end{abstract}

A fantástica viagem dos Argonautas em busca do Velo de Ouro faz parte de um antiquíssimo património narrativo de civilizações do Mediterrâneo oriental. Uma figura heróica, acompanhada de um amigo ou de um grupo de companheiros, aventura-se a percorrer espaços desconhecidos e cheios de perigos, com o fito de encontrar e se apoderar de um objecto que confere poder ou especiais poderes.

É já pressuposto o conhecimento divulgado das aventuras de Jasão e dos seus companheiros da nau Argo por parte dos ouvintes da poesia de Homero. O próprio poeta estabelece a anterioridade da viagem dos Argonautas em relação à de Ulisses, pondo na boca de Circe as advertências para a navegação propícia do herói ao passar junto às Rochas Planctas (12.69 sqq. $)^{1}$ :

Por ali só passou uma nau preparada para o alto mar,

A nau Argo, conhecida de todos, vinda da terra de Aetes.

$\mathrm{E}$ até essa teria o mar lançado contra as rochas ingentes,

Se por causa do amor de Jasão Hera não tivesse feito passar a nau. 2004 .

${ }^{1}$ Cito a tradução de Frederico Lourenço, Homero. Odisseia, introd. trad., Lisboa, 
Para além da anterioridade do mito, sublinham estes versos a sua enorme divulgação, fazendo dele património comum dos possíveis ouvintes da Odisseia ${ }^{2}$.

O mesmo mito dessa viagem das viagens ofereceu matéria inspiradora à poesia grega, lírica e dramática ${ }^{3}$. Destacam-se duas das obras sobreviventes - a mais longa das odes de Píndaro, a Pítica IV, e a Medeia de Eurípides.

Como convém à celebração da vitória nas competições desportivas, o enaltecimento do vencedor das corridas de carros, Arcesilau, soberano de Cirene, é amplificado pela típica associação pindárica a momentos de um mito ${ }^{4}$ em que ressaltam os feitos de uma figura heróica. São esses os contornos de Jasão no poema, saudado, desde o início, como o herói capitão da expedição pelos seus companheiros. O papel de uma Medeia, tocada por Afrodite, para o auxiliar, através da magia, a superar as tarefas que levariam à posse do Velo de Ouro está consagrado na ode. É a um Jasão decidido e autoconfiante que essa ajuda é prestada, como um reforço da sua própria natureza, e é com esse mesmo espírito e coração decidido que Jasão rapta Medeia para a desposar e levar para a Hélade.

O motivo essencial para a escolha desta saga, por parte de Píndaro, está na origem ancestral da casa do vencedor num dos heróis companheiros de Jasão, Eufemo.

Radicalmente diverso é o tratamento euripidiano da figura de Jasão que, já em solo grego, trai Medeia, a jovem princesa maga de outrora que traiu os seus e abandonou a Cólquide por amor, abandonando-a ele, agora, pela ambição do poder conseguido pelo casamento com a princesa de Corinto. A quebra de compromissos e juramentos do Grego e o pathos e a violência da paixão da princesa bárbara traída ressaltam no drama euripidiano, em que é perceptível a intenção da crítica à fragilidade ética do comportamento grego 5 .

${ }^{2} \mathrm{O}$ mito é também conhecido pelo poeta da Ilíada, que a ele se refere em $7.467 \mathrm{sqq}$.

${ }^{3}$ Quanto ao seu tratamento na poesia épica, é difícil dizermos qual a extensão que mereceu em As Corintiacas, poema perdido da autoria de Eumelo.

${ }^{4}$ E. Suárez de la Torre comenta, com razão, que a ode da vitória propriamente dita seja a Pítica V, enquanto esta, por referências contemporâneas que encerra, parece ser mais de enaltecimento do governante (Pindaro. Obra completa, introd. trad. anot., Madrid, 1988, p. 169).

${ }^{5}$ Lembremo-nos das peças de guerra, que tomam como mito inspirador o do destino da casa real de Tróia: Hécuba, Troianas, Andrómaca, ou então Ifigénia entre os Tauros. 
No entanto, o tratamento poético da expedição dos Argonautas, feito de forma sistemática, $a b$ ovo, até ao regresso dos heróis à Hélade, aparece-nos, pela primeira vez, na epopeia de Apolónio de Rodes, ou melhor, de Apolónio de Alexandria. Este homem - o único - de entre os grandes nomes da cultura helenística natural de Alexandria, nasceu no dealbar do séc. III a. C.

Se o Helenismo cultivou o gosto pela recuperação de jóias poéticas do património artístico da Hélade da época arcaica e clássica, bem como a subtil e elaborada miscigenação de referências e cânones ancestrais na produção estética do seu tempo, podemos considerar Apolónio como o homem certo na posição certa para o poder fazer. A sua cultura - parece ter sido discípulo de Calímaco - levou-o a ocupar o cargo de bibliotecário de Alexandria. Era, pois, privilegiado o seu acesso ao registo escrito do património estético-cultural da Hélade do passado. Essa mesma cultura esteve na origem da sua função de preceptor de Ptolemeu III, o Evérgeta.

Dado que a dinastia ptolemaica entendia ter raizes ancestrais na Cólquide, não é de afastar a hipótese, de resto já formulada por Hunter $^{6}$, de Apolónio se ter sentido atraído pelo propósito de consagrar poeticamente essa ligação, pela escrita da sua epopeia, chamando a si uma função que, de certo modo, o colocava em situação análoga à de Píndaro, ao compor a Pítica IV. Arcesilau de Cirene pertencia à casa dos Batíadas, descendentes do mítico Bato, que, por sua vez, descendia de Eufemo, companheiro de Jasão.

A narrativa épica, que tem início na partida de Iolco e termina com o regresso dos Argonautas à Hélade, corta com os parâmetros genológicos do começo in medias res e assume uma linearidade que permite uma identificação adivinhada e, por vezes, sugerida na escrita, entre a viagem e a tarefa de um narrador interventivo e não ausente? diverso do dos Poemas Homéricos. Tome-se, como exemplo, no episódio do desaparecimento de Hilas, fatalmente atraído para a corrente

${ }^{6} \mathrm{O}$ poema no contexto ptolemaico é analisado com toda a acuidade por R. Hunter, The Argonautica of Apollonius, Cambridge, 1993, pp.152-162.

${ }^{7}$ Veja-se R. Hunter, Op. cit. p. 120 sqq. ("the poem is the voyage", p.120). Veja-se, também, o excelente estudo deste aspecto do poema feito, de modo sistemático, por R. V. Albis, Poet and Audience in the Argonautica of Apollonius, Lanham, 1996, em especial no cap. 3 "The Poet's Voyage", em que o autor analisa muitas das formas ambiguas, utilizadas por Apolónio, para fazer o seu narrador referirse ao acto de narrar, que sugerem o movimento, no espaço e no tempo, que acompanha a própria acção narrada.. 
do rio pela ninfa enamorada, a interrupção de um excurso, feita com a seguinte justificação (1.1220):

Mas isto far-me-ia desviar para longe do meu canto.

Essa mesma identificação abre espaço para a invasão do discurso épico por um tom lírico, como nota Brioso Sánchez ${ }^{8}$. É expressiva a patética apóstrofe a Eros, no canto IV, em que o narrador reconhece, no mito da epopeia, os males que afectam a humanidade de que ele é parte. Assim, a força dos efeitos de Eros, verbalizados, introduz num discurso de segunda pessoa referências ao eu poético e ao próprio curso do poema (4. 445-451):

Amor nefasto, grande calamidade a quem os homens tão grande ódio têm. De ti provêm as funestas discórdias, os gemidos e lamentos e, além destas, outras dores sem fim. Ergue-te e arma-te, ó deus, contra os filhos dos meus inimigos, conforme disparaste, contra o coração de Medeia, essa terrível loucura.

Como foi, então, que ela abateu Apsirto, com morte cruel, quando ele vinha ao seu encontro? Que o nosso canto o diga de seguida.

Esta apóstrofe, já na parte final da epopeia, condensa expressivamente a vivência do amor peculiar à poesia helenística, como um mal que se apossa, avassalador, da alma humana ${ }^{9}$. É esse o mal que dá origem ao pathos profundo de uma Medeia repartida entre a fidelidade à sua casa e a paixão por Jasão. Esta última vence por que é ela o instrumento necessário para o acesso ao Velo de Ouro. R. Hunter ${ }^{10}$ diz deste passo "perhaps the most famous of Apollonius' 'intrusions' into his narrative is the apotropaic denunciation of eros before the morder of Apsyrtos".

Assim, o tema central de Os Argonautas descai, a partir do canto III, da viagem para o amor, entrelaçando-se viagem e amor porventura não de todo correspondido - no canto IV. Trata-se, decididamente, de uma inovação no tratamento épico do mito que aponta para novas modalidades narrativas dentro de um padrão de assimetria estranho à epopeia arcaica. O modo como cada uma das

${ }^{8}$ Apolonio de Rodas. Las Argonáuticas, introd. trad. Madrid, $2003^{3}$, pp. $10 \mathrm{sqq}$.

9 Veja-se A. Lesky, Vom Eros der Hellenen, 1976, pp. 123 sqq. O insigne helenista refere que a presença de eros no poema se encontra sob o signo das dissonâncias (na caracterização de cada um dos elementos do par e na relação entre eles), demonstrando que essa dissonância corresponde à sensibilidade da época em relação à vivência amorosa.

${ }^{10}$ Op. cit. p. 116. 
figuras do par Jasão-Medeia vive a relação amorosa com o outro contribui, de forma determinante, como se verá, para a caracterização dessas figuras.

Jogando com o nome da Musa, Erato, e o mais importante motor de acção no canto III, eros, o poeta começa por invocar a assistência da deusa para o seu mester narrativo, deduzindo do seu nome a sua natureza, participante dos poderes de Cípris (3.1-5):

Vamos, Erato, assiste-me agora e diz-me então como foi que Jasão trouxe o velo para lolco, por obra do amor (hyp 'eroti) de Medeia. É que tu tomas parte no poder de Cípris e com teus cuidados enfeitiças donzelas indómitas; por isso te está ligado um nome que fala de amor (eperaton).

Longe do fulgor da arete homérica, que só na sua visibilidade dos feitos do aristos, à luz, por todos reconhecido, se realiza ${ }^{11}$, Jasão e os Argonautas, ocultam a nau, num canal, a coberto da vegetação, ao chegarem à Colquide, e escondem-se. Este gesto é sintetizado por uma expressão de carácter paradoxal, não isenta de ironia (3.6-7):

Sem ser vistos ... ali esperavam os heróis (aristees) em emboscada. Mas avistaram-nos as deusas ...

Este quadro dos heróis emboscados sugere uma espécie de aporia frente à tarefa que os trouxe de Iolco à Cólquide ${ }^{12}$.

A diérese bucólica do segundo verso citado separa o plano humano do plano da confabulação das deusas, dispostas a providenciar o bom sucesso da expedição, mas conscientes de que lhes escapam os meios para alcançar tal objectivo - o que contribui para converter o episódio numa espécie de arremedo do conhecido motivo épico do concílio divino.

Consoante já tem sido notado, este episódio assume traços de uma comédia de costumes. A acção passa-se no espaço doméstico divino fala Rowan Beye de "domesticização" da acção épica ${ }^{13}$-, o que favo-

${ }^{11}$ A dimensão luminosa da arete homérica foi objecto de um profundo estudo feito por D. Bremer, no capítulo dedicado à estrutura lumino-tenebrosa da Ilíada em Licht und Dunkel in der frühgriechischen Dichtung, Bonn, 1976, pp.21-108.

${ }^{12}$ Nota D. L. Clayman, "The Scepticism of Apollonius": M. A. Harder, R. F. Regtuit, G. C. Wakker (ed.), Apollonius Rhodius, Hellenistica Groningana 4, Leuven, Paris, Sterling, Virginia, 2000, p. 35 sqq. que a aporia parece constituir a essência da condição dos Argonautas.

${ }_{13}$ Epic and Roman in the Argonautica of Apollonius, Southern Illinois University, 1982, p. 8: "In both instances, the Callimachean and the Apollonian, the heroic detail has been domesticated". 
rece, no plano humano, o correspondente cenário de interior como espaço de tensão e conflito anímico e de sentimentos ${ }^{14}$. Hera e Atena reconhecem-se impotentes para levar a cabo o sucesso de Jasão e decidem solicitar o auxílio de Afrodite para que convença Eros, seu filho, a infundir na filha de Eetes uma paixão pelo Argonauta que a leve a facilitar-lhe acesso ao Velo de Ouro.

É uma Afrodite ocupada no lazer aristocrático de comprazimento em cuidar da sua bela cabeleira que as duas deusas vão encontrar nos aposentos íntimos da sua mansão - uma Afrodite também ela incerta do seu domínio sobre Eros, essa criança imprevisível, indomável e mal educada que só cede perante ameaças e promessas de um brinquedo novo por parte da mãe. Assim, as três deusas, rivais consagradas da saga troiana no juízo de Páris, são agora concebidas por Apolónio como três senhoras, aristocráticas e fúteis, dependentes dos caprichos de uma criança mimada.

Se este Eros apresenta uma típica configuração helenística, não o tem menos a atenção poética dada à criança, com correspondentes nas artes figurativas, e revelada no seu tratamento - atenção perfeitamente alheia à épica arcaica e de gosto crescente na narrativa a partir de Apolónio de Rodes.

As flechas de Eros surtem efeito. No entanto, o processo de apaixonamento de Medeia é descrito com um tal realismo e uma intensidade tal que converte o concílio divino quase num "fait divers", como se, sem ele, Medeia estivesse predisposta a apaixonar-se natural e fatalmente pelo estrangeiro desconhecido que chega, vindo de longínquas paragens, ao palácio de seu pai. Reconhece-se, aqui, um velho motivo do conto popular e percebe-se que a figura de Nausícaa e o seu fascínio por Ulisses ofereceram a Apolónio motivos inspiradores para conceber a sua Medeia frente ao estrangeiro Jasão ${ }^{15}$. O que, verdadeiramente, prende a atenção do poeta é o contraste, tão do gosto

${ }^{14}$ Não posso deixar de recordar, aqui, todo o conflito interior de Fedra, no Hipólito de Euripides, de que conhecemos a fase terminal. Também Fedra se vê avassalada por sentimentos irreprimiveis que colidem com o seu estatuto e deveres familiares. Esta tensão vive-a a mulher de Teseu, em silêncio, isto é, no seu intimo, no espaço da casa habitado pela mulher aristocrática na Atenas do séc. V a. C. Veja-se B. Goff, The Noose of the Words: Reading of Desire, Violence and Language in Euripides' Hippolythos, Cambridge, 1990, cap. I.

${ }^{15} \mathrm{Ch}$. Rowan Beye, op. cit. p. 132 sqq. A propósito do que chama a ambiguidade de Medeia, o autor aponta a associação, na figura, de duas tipologias femininas opostas, que terão como representantes duas deusas a quem ela anda associada pelo poeta: Hécate e Ártemis. 
helenístico, entre a leviana e cruel brincadeira de Eros e o sofrimento das suas vítimas (3. 280-290):

Com pés ligeiros e sem ser visto, o deus [Eros] franqueou o umbral, de olhos rutilantes. Insinuando-se, rente ao filho de Éson, encostou a ponta do dardo ao meio da corda do arco e, retesando ambos os braços, atirou sobre Medeia. A surpresa que as palavras tolhe apoderou-se do ânimo da jovem, enquanto o deus se retirava para fora da sala de altos tectos, com uma gargalhada. Mas o dardo queimava fundo, lá dentro, no seu coração, tal como uma labareda. Sem cessar, lançava o brilho dos seus olhos na direcção do Esónida, e enquanto no seu peito o coração lhe palpitava de angústia, e toda a lembrança lhe fugia, sentia a sua alma derreter naquele doce cuidado.

Dividida entre o pudor e a atracção, a jovem princesa, num primeiro momento, observa irresistivelmente o estrangeiro, a coberto dos seus véus. Mais tarde, no primeiro encontro a sós, fora do palácio, quando the vai entregar o unguento mágico, ora baixa os olhos, recatada, ora os dirige, incapaz de resistir, para o forasteiro.

Os silêncios com que Apolónio marca todo este movimento, em que se adivinha a tensão de um ânimo repartido e atormentado, são os silêncios de uma nova realidade de narrativa, apta a ser saboreada e reapreciada pelo acto de leitura, num novo contexto de recepção da poesia. Estava-se perante um público de leitores, cultos - e a leitura é um acto eminentemente individual, ainda que possa e deva ter coexistido com as leituras públicas (As Argonáuticas, segundo a tradição transmitida por algumas fontes teriam, sido objecto de uma leitura pública ${ }^{16}$ ) - e não já perante círculos de ouvintes da poesia oral, em festas ou reuniões comunitárias ${ }^{17}$.

Não é já a reprodução em discurso directo de um solilóquio interior de Medeia que o poeta-narrador nos oferece, mas uma forma narrativizada de discurso indirecto ${ }^{18}$, que faz transvazar o pathos amoroso

${ }^{16}$ Sobre a difícil questão das fontes biográficas de Apolónio de Rodes, veja-se M. García Teijeiro in: J. A. López Férez (coord.), História de la Literatura Griega, Madrid, $1988^{2}$, p.804 sqq.

17 Apesar de N. Holzberg, no seu livro Der antike Roman. Eine Einführung, Düsseldorf/Zürich, 2001, cap. II, rejeitar a derivação do romance antigo da epopeia e do teatro, considero aplicáveise ajustadas as considerações que tece sobre a interrelação do género romance com a sua apreciação por um público de leitores cultos, à interrelação epopeia helenística/ leitor culto do mundo helenístico. Veja-se também Ch. Rowan Beye, op.cit. p.22.

${ }^{18}$ R. Hunter, op. cit. p. 143 sqq. utiliza, muito oportunamente, a distinção entre as categorias de'narrativisé' e 'raconté', aplicadas por Genette na leitura de Proust. 
da personagem para a própria narração. É disso exemplo ilustrativo, entre outros que poderiam ser escolhidos, 3. 443-458:

De um modo admirável se destacava entre todos o filho de Éson, pela sua beleza e pela sua graça. Com os olhos postos nele, a jovem contemplava-o furtivamente, por entre o seu formoso véu, enquanto o coração se lhe consumia naquela dor e o espírito lentamente se movia e, como num sonho, voava atrás dos passos do estrangeiro que partia.

Então eles [os Argonautas], abandonaram o palácio apreensivos. Calcíope, por seu turno, para se proteger da cólera de Eetes, com os filhos se dirigiu ligeira para os seus aposentos. Logo a secundou Medeia. E a sua alma agitava-se no turbilhão de cuidados que os Amores despertam. Diante dos seus olhos passavam todas aquelas imagens: o porte dele, o manto com que se cobria, o modo como falava, como estava ali sentado no cadeirão e como partira do palácio. No fervilhar da sua mente pensava que não havia outro homem como ele e aos seus ouvidos continuamente soava aquela voz e aquelas palavras, tão doces para a alma, que ele pronunciara.

\section{A paixão perturba-lhe o repouso do sono e invade-lhe os próprios sonhos (3.617-632):}

Logo sonhos enganosos e funestos a vieram perturbar. Pareceu-lhe que aquele estrangeiro se submetia a tal prova, não porque fosse seu objectivo absoluto levar a pele do carneiro, e que tão pouco fora esse o motivo da sua vinda até à cidade de Eetes, mas para levá-la a ela, como legítima esposa, para sua casa; e sonhava que era ela mesma quem defrontava os touros e quem levava a tarefa a cabo sem esforço algum, mas que seus pais não cumpriam a promessa porque tinha sido ao estrangeiro, não à donzela, que haviam imposto o trabalho de jungir os touros. Por isso se levantava uma querela, sem decisão clara, entre os estrangeiros e seu pai. Ambas as partes punham nas suas mãos a sentença de acordo com os ditames do seu coração. Nesse momento, sem contemplações para com seus pais, preferia o estrangeiro. Então, uma dor amarga deles se apoderou e clamavam, furiosos. Foi com este clamor que o sonho a abandonou.

Porque fala o narrador de 'sonhos enganosos' (eperopees... oneiroi)? Não estamos perante o sonho que exorta à acção, próprio da epopeia homérica, quer sob o modelo da Dios hapate, quer sob o do disfarce divino de Atena, para exortar Nausícaa e a impelir a ir lavar a roupa nas margens do rio. Enganador é o sonho de Medeia a partir da perspectiva do narrador, que conhece os motivos de Jasão - a posse do Velo de Ouro - mas também pela perspectiva da própria Medeia, insegura, na sua paixão pelo estrangeiro, quanto às disposições de Jasão. Funde-se, pois, na narrativização do sonho, a subjectividade da personagem com a consciência do narrador, estando este em sintonia com o pathos da jovem princesa. 
A linguagem do sonho e a sua figuração, esbatida na hábil reelaboração do discurso indirecto, está mais próxima do tratamento trágico do motivo. O sonho, na tragédia, é preferencialmente organizado num linguagem simbólica que se oferece à descodificação motivadora de inquietação (e esta de acção), porque carregada de presságio. A agitação de Medeia é, aqui, a verdadeira razão de ser do componente de presságio no sono intranquilo, já que as imagens oníricas se revelam como o espaço de projecção da ansiedade e das angústias de Medeia e antecipam o que, nessa ansiedade, Medeia facilmente pressente - a escolha iminente, a ruptura com a família, pela traição imposta pelo fogo da paixão irresistível.

A troca de confidências entre as duas irmãs, Medeia e Calcíope, no espaço adequado dos aposentos de Medeia, é motivada pela reacção desesperada da jovem ao despertar do sonho. Apolónio esboça, com magistral subtileza, a correspondência entre a luta de sentimentos da princesa - entre a angústia que a impele a procurar a irmã e a vergonha pelo ímpeto de uma paixão que teria necessariamente de confessar - e o seu movimento desordenado nos aposentos privados, ainda a coberto da noite. Medeia levanta-se, num impulso, e, em vestes de dormir, prepara-se para abandonar o quarto; estaca, portas abertas, tolhida pelo pudor do que irá confessar a Calcíope, recua a atira-se sobre o leito, em lágrimas. Será este quadro que a denunciará a uma aia que avisa Calcíope. Finalmente, não será Medeia quem há-de chegar aos aposentos de Calcíope, mas esta quem virá junto ao leito de Medeia. Tudo se passa como se a jovem princesa permanecesse na intimidade do seu quarto, apesar do esforço para daí sair, prisioneira dos seus próprios sentimentos.

Própria da agitação da paixão é a versatilidade de disposição anímica. A cena da troca de confidências entre as duas irmãs mostra-nos uma Medeia capaz de passar do desespero e do temor atormentado dos seus sentimentos ao júbilo por ver aberta uma porta de aproximação a Jasão, uma centelha de esperança, através do pedido de auxílio de Calcíope, em que ela julga ler uma iniciativa do Argonauta (3. 724-726):

Assim falou. No seu peito o coração palpitava de júbilo. A sua bela face cobria-se de rubor e uma névoa de comoção lhe toldava os olhos.

No poema são as palavras de Calcíope que dão a Medeia o estímulo determinante para sair do palácio e levar a Jasão o auxílio. $\mathrm{Na}$ Odisseia é o sonho de Nausícaa que cumpre essa função, através da exortação de Atenas, disfarçada, para que a jovem vá lavar a roupa, sem que o verdadeiro motivo da deusa - a possibilidade do encontro 
com Ulisses - transpareça à jovem. Todavia, no aprestar do carro e na cena de partida da princesa com as aias (3. 838-843; 3. 869 sqq.), a que não falta a expansão descritiva operada por um símile de comparação a Ártemis, percebe-se a utilização poética da cena-modelo da partida de Nausícaa para o rio.

$\mathrm{Na}$ violência desta paixão que leva a jovem a pôr em prática os seus dons de magia, até ao tenebroso e mortífero olhar encantatório na cena da morte de Talos, percebe o leitor a presença de uma outra referência da tradição poética que se entrelaça com a de Nausícaa — a da Medeia de Eurípides, o dramaturgo do pathos incontrolável. Para a descrição da sintomatologia física do pathos amoroso em 3. 962-965 vai Apolónio colher inspiração em Safo, no famoso fragmento do ciúme ${ }^{19}$ :

Saia-lhe do peito o coração. Os olhos nublaram-se-lhe e um cálido rubor se apoderou da sua face. Falhavam-lhe as forças para erguer os joelhos e andar para a frente ou recuar...

Esta coexistência paradoxal de traços de Nausícaa e de Medeia trágica confere à figura a complexa tridimensionalidade de uma alma em sofrimento, contorsida e em tensão, que encontra eloquente paralelo na escultura helenística, como, de resto, já tem sido notado.

A jovem que pede abrigo, desamparada e frágil, junto de um Jasão algo reservado, depois de ter excitado a fúria paterna pela traição a que o amor a levou, é a mesma mulher que convoca Hécate nas trevas da noite, envolta em negro manto, e que, pela calada da noite, sai, acossada pela vergonha do seu gesto e pelo ímpeto da paixão, escondendo no seio os mágicos unguentos, para os entregar a Jasão.

Este, por sua vez, desde o início da empresa se distancia do tradicional modelo do herói épico. A chefia incontestada dos Argonautas cabe a Héracles, para quem todos os heróis olham quando chega o momento de eleger o capitão da nau, e apenas porque Héracles o determina, recebe Jasão a chefia. À partida está criado o clima para se perceber nele marcas de insegurança e a nostalgia de Iolco ou de um tempo em que a tarefa de conduzir os companheiros the não pesava sobre os ombros.

A dor a que alude, na despedida de sua mãe, e que com ele leva, é, sem dúvida, a do afastamento de casa e da incerteza do caminho e dos perigos que o espreitam (1.295 sqq.). No episódio de Fineu, em

${ }^{19}$ Frg. 31 Lobel-Page. Ch. Rowan Beye, op. cit. p.,138 aponta influência do frg. 47 Lobel-Page de Safo em Arg. 3. 967-971. 
particular, essa ansiedade ganha expressão por diversas vezes, quer na pergunta pelo regresso a casa (nostos, 2. 414) por parte de quem se considera ignorante entre ignorantes (neïs, 2.417), quer na formulação do desejo de ver Fineu na posse da visão - alegria igual à da hora do seu regresso a casa (2. 441-442). ${ }^{20}$

O motivo do nostos não é original na epopeia - ele anima, como é por demais sabido, a acção da Odisseia e o desejo do regresso constitui um dos traços constantes da caracterização de Ulisses. Certamente que tal motivo deve ter andado associado à tradição épica onde a temática da viagem figurava. O que se verifica de diferente em relação à Odisseia é que aí o desejo do regresso constitui uma constante após uma tarefa cumprida - a guerra de Tróia. O desenvolvimento poético da temática do nostos tem o seu lugar no momento em que representa uma preocupação natural do herói, após a guerra, e, mais ainda, ao longo do tempo em que, projectado o regresso, o herói é impedido, por obstáculos sucessivos, de chegar à pátria, perdido que anda no mar ou retido, contra vontade, em alguma estância, por interferência divina. A Jasão, em contrapartida, parece pesar a distância ainda antes de se afastar de Iolco. Sonha com o seu regresso e teme pelas dificuldades que nele há-de encontrar, ainda antes de cumprir a tarefa que o pôs a bordo da nau Argo, como seu capitão.

Por seu turno, nem a força da paixão de Medeia encontra em Jasão atracção equivalente, nem a determinação da jovem, com o seu auxílio de magia, encontra em Jasão o aristos confiante e sereno, totalmente destituído de receios. Ele reconhece que sem o auxílio de Medeia não levará a bom termo a sua tarefa. O encontro de ambos a sós, quando Medeia the leva escondido o unguento mágico, ilustra, de modo particularmente expressivo, a dissimetria do par. Jasão dirige-se à princesa apaixonada com palavras de sedução, de modo a captar a sua boa-vontade, sem todavia se aperceber da intensidade de sentimentos da interlocutora. Pede-lhe que o não engane com palavras hábeis e promete-lhe recompensa. O poeta realça o contraste com o generoso desprendimento, próprio de um ser apaixonado com a veemência de Medeia, criando um dos mais expressivos momentos de

${ }^{20}$ Ch. Rowan Beye, op. cit. p. 81 et passim, vê, com razão, este Jasão modelado sob o signo da nostalgia e da insegurança. Na sua nota 8 ao capitulo "The Heroes" (p. 183) cita os vários passos apontados por A. Couat, no seu livro Alexandrian Poetry Under the First Three Ptolemies, London, 1931, p. 41, que ilustram esta disposição anímica. 
silêncio na narrativa ${ }^{21}$, sublinhado pelo movimento do olhar da princesa (3.1008-1019):

Assim falou Jasão, lisonjeando-a; e ela baixou os seus olhos e sorriu de um modo divino. No seu íntimo enternecia-se-lhe a alma, exaltada pelo elogio recebido. Então olhou-o de frente. Não sabia que palavras the havia de dizer primeiro, já que tinha vontade de tudo lhe dizer de uma só vez. Prontamente, sem hesitações, tirou o unguento mágico do seu cinto perfumado e logo ele o recebeu nas suas mãos, com alegria. Ela, comovida, ter-lhe-ia dado toda a sua alma, arrancando-a do peito, se ele o tivesse desejado - tão doce era o brilho da chama que Amor fazia desprender da cabeça do Esónida. A ela arrebatava-lhe um brilho de seus olhos.

A sobreposição de mitos é cara ao gosto helenístico. Com ela joga Apolónio de Rodes. Começando a sentir os efeitos do Amor, muito mais tarde e mais tenuamente que Medeia, Jasão, perante as lágrimas e palavras magoadas da jovem, na cena nocturna do encontro a sós, promete levar Medeia consigo, tão gratamente quanto Teseu o fizera com Ariadne (3. 1079 sqq.), vinda em auxílio deste contra seu meioirmão.

A comum descendência do Sol aproxima Ariadne de Medeia. Há, no entanto, a intenção deliberada de criação de um efeito irónico, por parte do poeta, ao pôr tais palavras na boca de Jasão ${ }^{22}$. Conforme nota Hunter $^{23}$, a ironia desta sobreposição sugere ao leitor o desenlace da relação amorosa iminente, a partir do conhecimento prévio do mito e, em especial, do seu tratamento euripidiano - também Medeia será abandonada, longe da sua terra, após tudo ter posto em risco, e depois de o par de namorados, passando por aventuras e riscos na viagem fantástica de regresso à Grécia, ter conhecido a ameaça de perseguidores, de perigos em terras estranhas, como na Líbia, antecipando situações tão típicas do romance ${ }^{24}$. O perfil de Jasão apresenta já marcas da figura do anti-herói que há-de animar novos contextos narrativos.

Os diversos episódios eróticos entrelaçam-se, fundindo espaços e experiências, através da presença ou do uso de objectos que assumem

21 Sobre o silêncio na narrativa e a sua relação com o uso crescente de modalizações do discurso indirecto, veja-se Ch. Rowan Beye, op. cit. p. 22 sqq. bem como supra n. 17.

${ }^{22}$ Uma outra contaminação mitológica, menos sugestiva, é a de Jasão-Cadmo, através da sementeira de dentes do dragão.

${ }^{23}$ Op. cit. p. 117.

${ }^{24}$ Uma sintese das situações-estereótipo que nos aparecem no romance antigo são dadas por N. Holzberg, op. cit. p. 20 sqq. 
valor simbólico. Da viagem e da relação com a rainha Hipsípila, na permanência em Lemnos, traz Jasão o negro manto que o cobre na invocação a Hécate, propiciada por Medeia. Na união com Medeia, fora da Cólquide, no retorno à Grécia, está presente o Velo de Ouro, com o seu fulgor ${ }^{25}$.

O alargamento dos conhecimentos geográficos e da hidrografia a norte da antiga Hélade permite a Apolónio reorganizar, na sua imaginação, o espaço e o curso dos rios, de modo a converter a viagem dos Argonautas num percurso fantástico circular. A circularidade e a natureza fantástica desse percurso, assimétrica nas vivências e nos perigos vividos, como se pode verificar se recordarmos a estrutura do poema, reforça a sugestão de um itinerário quase iniciático de Jasão ${ }^{26}$ — primeiro através de ameaças de um mar desconhecido e de abismos intransponíveis que, uma vez transpostos, perdem o seu poder ameaçador, depois, arrostando o confronto com estranhos, com monstros como as aves do Estínfalo, ou a perda de companheiros, para chegar à posse de um objecto mágico, coincidente com o conhecimento do amor.

Fuga e regresso são marcados por essa posse e pela perda de uma espécie de inocência, através da consciência de traição e roubo, do desassossego da perseguição, da vergonha e má consciência pela crueldade da morte de Apsirto, pela necessidade de purificação do par Medeia-Jasão.

A morte afecta todos - tal como na viagem para a Cólquide, perdem-se companheiros queridos, agora em territórios hostis para onde a nau é lançada, como pela tyche da força do mar. Assim se hão-

${ }^{25}$ R. Hunter, op. cit. p. 47 sqq. vê no papel de Hipsípila correspondência ao papel de Calipso, na Odisseia, e em Medeia marcas da Circe homérica. Por seu turno, na preparação do herói para o encontro com ambas, Hipsípila e Medeia, vê o autor "an erotic rewriting of a Homeric warrior's preparations for a duel". De facto, a ekphrasis dos motivos do manto de Hipsípila lembra a função da do escudo de Aquiles, no famoso passo da Iliada.

${ }^{26}$ Comenta R. Hunter, op. cit. p.138: "The opening of the Rocks to human navigation which made the seas passable is the most strikink symbol of man's conquest of the oceans, a conquest which ancient poetry presents in two different, though intersecting, ways. On one hand, it is a triumph of Greek technology and the human spirit; on the other, it marks the original hybristic foolishness of men who refuse to accept divinely ordained limits, and is the start of moral decay.

Sobre a dimensão iniciática da viagem veja-se a obra de J. J. Clauss, The Best of the Argonauts. The Redefinition of the Epic Hero in Book 1 of Apollonius's Argonautica. Berkeley - Los Angeles - Oxford, 1993, cap. 7. 
de encontrar na Líbia, descrita com um vivo realismo, onde até Medeia parece perdida e esquecida do poder da sua magia.

A revelação desse poder funesto que Medeia traz consigo e faz actuar às portas da antiga Hélade, no episódio do encantamento do brônzeo gigante Talos, traz outra revelação consigo sobre a fragilidade do destino humano, tão do gosto da literatura helenística e, posteriormente, da latina - a impotência humana perante a acção dos poderes, ocultos e nefastos, da feitiçaria. Essa revelação afecta profundamente o narrador, que ganha voz e uma identidade ainda mais evidente no fim do poema (4. 1673-1677):

Zeus pai, grande é o assombro que se apodera do meu espírito ao ver que não é só com doenças ou ferimentos que a morte funesta vem ao nosso encontro! Até à distância pode alguém fazer-nos mal! Assim aconteceu a Talos que, apesar de ser de bronze, se deixou abater pelos poderes de Medeia, a de muitos feitiços.

O carácter fantástico do périplo coexiste com a observação minuciosa de paisagens e ambientes descritos com notável realismo. Lembremos, entre outras, mais uma vez, a da inóspita Líbia.

A mesma capacidade de observação preside ao tratamento de um dos recursos típicos da epopeia - o símile. Já nos Poemas Homéricos, a par dos abundantes símiles que recorrem à vida selvagem, como os de aves, abelhas, leões ou cavalos que correm pela pradaria, encontramos outros, bastante menos frequentes, que tomam como campo de inspiração o quotidiano da actividade humana, como a pastorícia, a agricultura, a arte de trabalhar barro ou metais, e até, num caso, o comércio de lã e a necessária tarefa de a pesar na balança. Em $A s$ Argonáuticas, todavia, embora os fenómenos da natureza e da vida selvagem continuem a fornecer temática inspiradora para estas longas comparações, essa realidade do quotidiano começa a tomar a primazia como campo inspirador de símiles - a actividade do carpinteiro, do construtor de navios, do agricultor ou do pastor, cenas de caça ${ }^{27}$.

${ }^{27}$ R. Hunter, op.cit. pp.129-138, demonstra, com extrema acuidade, que o tratamento do simile em Apolónio serve fins mais subtis e complexos que o símile homérico, destinado a apoiar a imaginação do ouvinte. Em Apolónio de Rodes a própria estratégia discursiva do símile desempenha funções miméticas da acção que pretende ilustrar (pp.137-138, dando como exemplo, 2. 541-548) e, não raramente, aparenta parênteses intrusivos destinados a envolver o leitor nesse percurso de verificação de correspondências entre o discurso, o plano comparativo, e a 'realidade ficcional' comparada. Assim o símile ganha em polissemia e o texto épico adquire uma espécie de sentido segundo. 
Dentro desta tendência de estabelecimento de uma relação mais forte entre o objecto da narrativa e a realidade histórico-cultural contemporânea do poeta se inscreve a preocupação em assinalar, no mito, a sua dimensão etiológica, a origem de hábitos, designações, ritos em vigor - preocupação que tem já presença na tragédia euripidiana, no tratamento do recurso ao deus ex machina, através do qual o poeta estabelece um nexo entre rituais seus contemporâneos e o momento da sua fundação, na acção trágica.

Por outro lado, a magnitude dos espaços que constituem o cenário de grandes percursos coexiste com a descrição e a movimentação em espaços domésticos, de interior, quer no plano divino, onde a 'comédia de costumes' decorre, quer no plano humano.

Este espaço de interiores, no palácio de Eetes, sintoniza com o drama interior de Medeia. Ele é adequado para o exacerbar de paixões insuspeitadas, tal como acontece com o espaço que sabemos ser o habitado por Fedra, no Hipólito de Eurípides. É o espaço de presença feminina, próprio das confidências e conivências, da intimidade e da perturbação dessa intimidade, adivinhada nos silêncios da narrativa, de que atrás se falou - intimidade que transborda para o mundo interior de um narrador que com ela joga, que a acolhe, através, como foi dito, do uso, em modalidades diversificadas, do discurso indirecto ${ }^{28}$. Tratase de uma tendência da ficção narrativa que não é alheia ao fenómeno de desdramatização da narrativa épica, como já o notou Hunter ${ }^{29}$.

Este narrador, cada vez mais interventivo, prevalecente e consciente do seu estatuto, com que aprende a jogar, ganha espaço numa cultura que é, cada vez mais, do livro e da leitura. Ele há-de vir a conhecer e a dominar gradualmente, todo um universo de possibilidades interventivas que, pouco a pouco, nesse movimento de constante fecundação entre o património da tradição poética, as novas realidades e contextos culturais e sociais e a capacidade de reinvenção artística, hão-de fazer germinar o romance ${ }^{30}$.

${ }^{28}$ Vide supra $\mathrm{n} .18$.

${ }^{29}$ Ibid. p. 13.

${ }^{30}$ P. Fedeli, "Il Romanzo": G. Cavallo, P. Fedeli, A. Giardina (dir.), Lo Spazio Letterario di Roma Antica, Roma, vol. I, pp. 343-346, sustenta a tese de que o romance nasce das cinzas da epopeia, salientando que esse processo de desajustamento dos heróis épicos a contextos socio-culturais de épocas que já se não identificam, de modo algum, com tais modelos constitui um fenómeno que ultrapassa o mundo antigo e que se pode observar em culturas posteriores. Verifica ainda P. Fedeli, com toda a pertinência, que "è singolare che sull'origine del romanzo le posizioni degli studiosi di narrativa antica finiscano per saldarsi con quelle degli studiosi di narrativa moderna" (p. 345). 